Georgetown University Law Center

Scholarship @ GEORGETOWN LAW

2011

\title{
The Evolution of International Environmental Law
}

Edith Brown Weiss

Georgetown University Law Center, weiss@law.georgetown.edu

This paper can be downloaded free of charge from:

https://scholarship.law.georgetown.edu/facpub/1669

54 Japanese Y.B. Intl. L. 1-27 (2011)

This open-access article is brought to you by the Georgetown Law Library. Posted with permission of the author.

Follow this and additional works at: https://scholarship.law.georgetown.edu/facpub

Part of the Environmental Law Commons 


\section{ARTICLES}

\section{THE CONTRIBUTION OF INTERNATIONAL ENVIRONMENTAL LAW TO INTERNATIONAL LAW: PAST ACHIEVEMENTS AND FUTURE EXPECTATION}

\section{THE EVOLUTION OF INTERNATIONAL ENVIRONMENTAL LAW}

\section{Edith Brown Weiss*}

Introduction

I. From 1900-1972: Early Glimmers

II. From 1972-1992: Development of Basic Framework

1. 1972: The United Nations Stockholm Conference on the Human Environment

2. After the Stockholm Conference

III. From 1992-2012: Maturation and Linkage

1. 1992: The United Nations Rio Conference on Environment and Development

2. After the Rio Conference

Concluding Observations

\section{Introduction}

In the last forty years, international environmental law has evolved rapidly, as environmental risks have become more apparent and their assessment and management more complex. In 1972, there were only a few dozen multilateral agreements, and most countries lacked environmental legislation. In 2011, there are hundreds of multilateral and bilateral environmental agreements and all countries have one or more environmental statutes and/or regulations. Many actors in addition to States shape the development, implementation of, and compliance with international environmental law. Moreover, environment is increasingly integrated with economic development, human rights, trade, and national security. Analyzing the evolution of international environmental law helps us understand the possibilities and the limitations of law in addressing environmental problems, whether globally, regionally, or locally.

The evolution of international environmental law can be separated into three distinct periods: from 1900-1972; from 1972-1992; and from 1992-2012. These cor-

- Francis Cabell Brown Professor of International Law, Georgetown Law, Washington, D.C., USA. The author thanks Alice Bullard, Ph.D., for research assistance. 
respond roughly to the period of early glimmers of international environmental law; basic framework development; and maturation and linkage with other areas of international law. The periods are demarcated by two international conferences: the 1972 United Nations Stockholm Conference on the Human Environment (Stockholm Conference) and the 1992 Rio de Janeiro Conference on Environment and Development (Rio Conference). In June 2012, the Rio+20 Conference will be held, again in Rio de Janeiro. Both the prior Stockholm and Rio Conferences were path breaking. Their work products and the events surrounding them laid the basis for significant leaps forward in developing and implementing international environmental law.

\section{From 1900-1972: Early Glimmers}

Concern for the environment is ancient and embedded in the major religious traditions. In the Judeo-Christian tradition, for example, God gave the earth to his people and their offspring as an everlasting possession to be passed down to each generations and exhorted people not to cut down fruit bearing trees during warfare. ${ }^{1}$ Other religions similarly show respect for nature. ${ }^{2}$ For centuries, countries have developed rules for the use of shared watercourses and rights to water. However, before 1900 few international agreements were concerned with international environmental issues. The prevailing rule of international law was that of national sovereignty over natural resources within a country's territory or jurisdiction. The few international agreements focused primarily on boundary waters, navigation, and fishing rights. With few exceptions, they did not address pollution issues. ${ }^{3}$

In the early twentieth century, countries concluded at least four agreements to protect species of commercial value, including migratory birds, birds useful to ag-

1 Genesis 1: 1-31, 17: 7-8, and Deuteronomy 20: 19.

2 The nontheistic tradition of Shinto stresses respect for nature, a view for which there is resonance in Buddhism, Hinduism and Jainism. Japan has a reverence for nature that is displayed in symbolic representations, such as flying cranes on wedding kimonos. For recent discussion, see Bruce Rich, To Uphold the World: A Call for a New Global Ethic From Ancient India (2010), pp. 168-169. Islamic law regards each generation as having inherited "all the resources of life and nature" and having certain duties to God in using them. See Abou Bakr Ahmed Ba Kadar et al., Islamic Principles for the Conservation of the Natural Environment (2nd ed., 1983), pp. 13-14.

3 A notable exception is the 1909 United States-United Kingdom Boundary Waters Treaty, which provided in Article IV that water "shall not be polluted on either side to the injury of health or property on the other." Washington Treaty Relating to Boundary Waters between the United States and Canada, January 11, 1909, Charles Bevans, Treaties and Other International Agreements of the United States of America 1776-1949, Vol. 12, p. 319 (Treaty Series No. 548). 
riculture, fur seals, and wild animals, birds and fish in Africa. ${ }^{4}$ During the 1930 s and 1940s, countries concluded several agreements aimed at protecting fauna and flora in specific regions, namely the Western Hemisphere and Africa. ${ }^{5}$ They also negotiated agreements concerned with marine fisheries and concluded the landmark International Convention for the Regulation of Whaling. ${ }^{6}$ In the period between 1950 and 1970, States focused on two environmental problems, marine pollution from oil and damage from civilian use of nuclear energy, and negotiated several agreements.7 By the late 1960s, environmental concerns had broadened. States concluded an African Convention on the Conservation of Nature and Natural Resources in 1968 and the Ramsar Convention on Wetlands in 1971. ${ }^{8}$ Still, there were few international environmental agreements concluded before 1972.

During these early years in international environmental law, there was little development of international environmental rules or principles. Two famous arbi-

4 Canada-United States of America: Convention for the Protection of Migratory Birds in the United States and Canada, August 16, 1916, Charles Bevans, Treaties and Other International Agreements of the United States of America 1776-1949, Vol. 12, p. 375 (Treaty Series No. 628); Convention for the Protection of Birds Useful to Agriculture, March 19, 1902, Clive Parry, ed., Consolidated Treaty Series, Vol. 191, p. 91; Treaty for the Preservation and Protection of Fur Seals, June 7, 1911, Statutes at Large of the United States of America, Vol. 37, p. 1542; and London Convention for the Protection of Wild Animals, Birds and Fish in Africa, May 19, 1900, British and Foreign State Papers, Vol. 94, p. 715.

5 Washington Convention on Nature Protection and Wildlife Preservation in the Western Hemisphere, October 12, 1940, United Nations Treaty Series, Vol. 161, p. 193 (No. 485). London Convention relative to the Preservation of Fauna and Flora in their Natural State, November 8, 1933, League of Nations Treaty Series, Vol. 172, p. 241.

6 Washington International Convention for the Regulation of Whaling, December 2, 1946, United Nations Treaty Series, Vol. 161, p. 72 (No. 2124); Washington International Convention for the North-West Atlantic Fisheries, February 8, 1949, United Nations Treaty Series, Vol. 157 , p. 157 (No. 2053); Tokyo International Convention for the High Seas Fisheries of the North Pacific Ocean, May 9, 1952, United Nations Treaty Series, Vol. 205, p. 65 (No. 2770).

7 For example, International Convention for the Prevention of Pollution of the Sea by Oil, May 12, 1954, United Nations Treaty Series, Vol. 327, p. 3, (No. 4714); Tanker Owners Voluntary Agreement concerning Liability for Oil Pollution, January 7, 1969, International Legal Materials, Vol. 8 (1969), p. 497; Bonn Agreement for Co-operation in Dealing with Pollution of the North Sea by Oil, June 9, 1969, United Nations Treaty Series, Vol. 704, p. 3 (No. 10099); Vienna Convention on Civil Liability for Nuclear Damage, May 21, 1963, United Nations Treaty Series, Vol. 1063, p. 265 (No. 16197), amended by the Protocol of September 12, 1997 (consolidated text, International Atomic Energy Association Document INFCIRC/566 (1998), Annex).

8 African Convention on the Conservation of Nature and Natural Resources, September 15, 1968, United Nations Treaty Series, Vol. 1001, p. 3 (No. 14689); Ramsar Convention on Wetlands of International Importance Especially as Waterfowl Habitat, February 2, 1971 (amended December 3, 1982), United Nations Treaty Series, Vol. 996, p. 245 (No. 14583). 
trations took place, the Trail Smelter Arbitration' between Canada and the United States, and the Lac Lanoux Arbitration between France and Spain. ${ }^{10}$ The former dealt with the obligation not to cause transboundary harm, and the latter with procedural obligations of prior notification, consultation, and negotiation. These decisions have been cited repeatedly in later writings on international environmental law, in part because few other relevant decisions exist during this period.

\section{From 1972-1992: Development of Basic Framework}

This period begins with the 1972 United Nations Conference on the Human Environment and includes the many developments that took place up until the 1992 United Nations Conference on Environment and Development.

1. 1972: The United Nations Stockholm Conference on the Human Environment

The year 1972 was historic, because for the first time countries across the world came together to identify and address environmental problems. The United Nations Conference on the Human Environment, held in Stockholm in 1972, was the first international intergovernmental conference to focus on environmental problems. The preparations for the Conference, the Conference, and the period immediately following the Conference had lasting consequences for the course of international environmental law.

Perhaps the most central issue that arose in the preparations for the Stockholm Conference was the need to address the potential conflict between economic development and environmental protection. Developing countries were especially concerned that an international effort to protect the environment would come at the expense of their own development. Shortly before the Conference, a group of experts from governments, academia, and nongovernmental organizations met in Founex, Switzerland, to discuss the conflicts and develop a conceptual framework for reconciling environmental protection and economic development. The Founex report recognized that environmental protection and economic development could

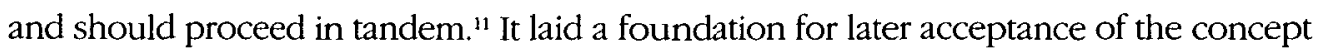

9 Trail Smelter Case (United States v. Canada), Ad Hoc International Arbitral Tribunal, March 11, 1941, United Nations Reports of International Arbitral Awards, Vol. 3 (1949), p. 1938.

10 Lake Lanoux Case (France - $v$. Spain), Ad Hoc International Arbitral Tribunal, November 16, 1957, United Nations Reports of International Arbitral Awards, Vol. 12 (1963), p. 281.

1 Founex Report on Development and Environment (1971). The report is reprinted in Miguel Ozorio de Almeida et al., Environment and Development; the Founex Report on Development and Environment, witb Commentaries (1972). 
of sustainable development, which governments confirmed as an overarching policy twenty years later at the Rio Conference on Environment and Development.

The Stockholm Conference also resulted in the adoption by governments of the U.N. Stockholm Declaration on the Human Environment. This document set the stage for the further development of principles of international environmental law. ${ }^{12}$ In particular, Principle 21, which provides that "States have [...] the sovereign right to exploit their own resources pursuant to their own environmental policies, and the responsibility to ensure that activities within their jurisdiction or control do not cause damage to the environment of other States or of areas beyond the limits of national jurisdiction," sets forth a basic obligation, which the International Court of Justice subsequently recognized as part of international law. ${ }^{13}$

As a result of the Stockholm Conference, countries established the first international intergovernmental organization focused on environmental protection: the United Nations Environment Programme (UNEP) in Nairobi, Kenya. The organization was not established as a United Nations specialized agency, however, and thus lacks the status of other United Nations organizations such as the United Nations Food and Agricultural Organization (FAO) or the United Nations Educational, Scientific, and Cultural Organization (UNESCO). ${ }^{14}$ The issue of institutional governance is one of the key issues in preparations for the Rio+20 conference in June 2012. The decision to locate UNEP in Kenya was especially significant, because the specialized United Nations agencies were all located in developed countries. UNEP's location sent a signal that environmental problems were endemic to all countries.

The Stockholm Conference also heralded the emergence of nongovernmental organizations, and to a lesser extent other elements of the private sector, as concerned participants in the discussion of international environmental issues and in the development of international environmental law. The United Nations accredited 250 nongovernmental organizations for the Stockholm Conference, which at that

12 Stockholm Declaration of the United Nations Conference on the Human Environment, Report of the United Nations Conference on the Human Environment, U.N. Doc. A/ CONF.48/14/Rev.1 (1973), p. 3; U.N. Doc. A/CONF.48/14 (1972), pp. 2-65. and Corr. 1.

13 Legality of the Threat or Use of Nuclear Weapons, Advisory Opinion, I.C.J. Reports 1996, p. 226; and Gabčíkovo-Nagymaros Project (Hungary v. Slovakia), Judgment, I.C.J. Reports 1997, p. 7

14 All member countries belong to the governing body of the specialized agencies, while UNEP's Governing Council includes only some of the member countries. The specialized agencies are established by international agreement and by Articles 57 and 63 of the United Nations Charter, and are linked to the U.N. Economic and Social Council. UNEP was established by U.N. General Assembly Resolution 2997 (XXVII) of December 15, 1972, and reaffirmed by U.N. General Assembly Resolution, U.N. Doc. A/RES/31/112, December 16, 1976. UNEP is linked to the United Nations General Assembly. 
time was noteworthy. ${ }^{15}$

Several important multilateral agreements are associated with the Stockholm Conference, namely the 1972 Convention for the Prevention of Marine Pollution by Dumping of Wastes and Other Matter, the 1972 Convention for the Protection of World Cultural and Natural Heritage, and the 1973 Convention on International Trade in Endangered Species of Wild Fauna and Flora (CITES). ${ }^{16}$ These agreements have been early pillars of international environmental law. Most countries are parties to CITES and to the World Heritage Convention, and many to the one on marine pollution by dumping.

In every field of international law, one can point to catalytic events for the growth of the field. The developments highlighted above, together with the UN Conference itself, set the stage for the rapid expansion in international environmental law during the next two decades.

\section{After the Stockholm Conference}

In the two decades that followed the Stockholm Conference, international environmental agreements proliferated. By the end of the period, there were more than 1100 international legal instruments that were either fully concerned with the environment or had important provisions relating to the environment. This number includes both binding agreements and nonbinding legal instruments, such as the U.N. Stockholm Declaration on the Human Environment. ${ }^{17}$

In this period, countries became adept at negotiating new agreements in a relatively short time frame, often less than two years. Even the intergovernmental negotiations for the U.N. Framework Convention on Climate Change took only 16 months to reach agreement. ${ }^{18}$ Generally, it took longer for the agreements to come into effect than to negotiate.

is Michele M. Betsill and Elisabeth Corell, eds., NGODiplomacy: The Influence of Nongovernmental Organizations in International Environmental Negotiations (2008), p. viii.

16 International Maritime Organization Convention for the Prevention of Marine Pollution by Dumping of Wastes and Other Matter, December 29, 1972, United Nations Treaty Series, Vol. 1046, p. 120 (No. 15749) and London Protocol, November 7, 1996, IMO LC/SM1/6 (1996), reprinted in International Legal Materials, Vol. 36 (1997), p. 1; UNESCO Convention for the Protection of World Cultural and Natural Heritage, November 16, 1972, United Nations Treaty Series, Vol. 1037, p. 151 (15511); and Washington Convention on International Trade in Endangered Species of Wild Fauna and Flora (CITES), March 3, 1973, United Nations Treaty Series, Vol. 993, p. 243 (No. 14537), amended in Bonn on June 22, 1979.

17 Stockholm Declaration of the United Nations Conference on the Human Environment, June 16, 1972, supra note 12.

18 United Nations Framework Convention Climate Change (UNFCC), May 21, 1992, United Nations Treaty Series, Vol. 1771, p. 107 (No. 30822). 
The pattern of international environmental agreements was one of separate agreements for specific problems, each with its own system of monitoring and reporting, own secretariat, and often its own, separate, financing facility to assist countries in implementing the agreement. This led to the observation by 1993 that there was "treaty congestion" and the system needed to become more efficient. ${ }^{19}$

The concept of a framework agreement, supplemented by one or more protocols to address specific problems, also emerged during this period. Soon after UNEP was established, States concluded agreements under UNEP to protect specific regional seas. The agreements took the form of a framework agreement setting forth general provisions, with one or more protocols addressing specific aspects of protecting the regional sea. ${ }^{20}$ If a State were to become party to the framework agreement, it also had to join one or more of the protocols attached to it. This procedure was intended to ensure that the agreements would have "teeth" in protecting the regional sea. The pattern of a framework agreement with separate protocols subsequently became the prototype for the negotiation of many other international agreements, including for long-range transboundary air pollution, ${ }^{21}$

19 Edith Brown Weiss, "International Environmental Law: Contemporary Issues and the Emergence of a New World Order," Georgetown Law Journal, Vol. 81, No. 3 (1993), pp. 675-710.

20 E.g., Barcelona Convention for the Protection of the Mediterranean Sea against Pollution, February 16, 1976, United Nations Treaty Series, Vol.1102, p. 27 (No 16908).

${ }^{2 t}$ Economic Commission for Europe Convention on Long-Range Transboundary Air Pollution (LRTAP), November 13, 1979, E/ECE/1010 (1979), United Nations Treaty Series, Vol. 1302, p. 217 (No. 21623); Helsinki Protocol to the 1979 Convention on Long-Range Transboundary Air Pollution on the Reduction of Sulphur Emissions or their Transboundary Fluxes by at Least 30 Percent, July 8, 1985, United Nations Treaty Series, Vol. 1480, p. 215 (No. 25247); Sofia Protocol to the 1979 Convention on Long-Range Transboundary Air Pollution Concerning the Control of Emissions of Nitrogen Oxides or Their Transboundary Fluxes, October 31, 1988, United Nations Treaty Series, Vol. 1593, p. 287 (No. 27874); Geneva Protocol to the 1979 Convention on Long-Range Transboundary Air Pollution Concerning the Control of Emissions of Volatile Organic Compounds or Their Transboundary Fluxes, November 18, 1991, United Nations Treaty Series, Vol. 2001, p. 187 (No. 34322); Oslo Protocol to the 1979 Convention on Long-Range Transboundary Air Pollution on Further Reduction of Sulfur Emissions, June 14, 1994, U.N. Doc. ECE/EB.AIR/40 (1994), United Nations Treaty Series, Vol. 2030, p. 122 (No. 21623); Åarhus Protocol to the 1979 Convention on Long-Range Transboundary Air Pollution on Heavy Metals, June 24, 1998, United Nations Treaty Series, Vol. 2237, p. 4 (No. 21623); Áarhus Protocol to the 1979 Convention on Long-Range Transboundary Air Pollution on Persistent Organic Chemicals, June 24, 1998, United Nations Treaty Series, Vol. 2230, p. 79 (No. 21623). 
ozone ${ }^{22}$ climate, ${ }^{23}$ and tobacco control. ${ }^{24}$ However, the requirement that a State must join a protocol when becoming a party to the framework agreement did not survive.

As developed elsewhere in detail, the period between 1972-1992 witnessed changes in the themes and in the focus of international environmental agreements. ${ }^{25}$ The scope expanded from agreements controlling transboundary pollution to ones addressed to global pollution problems, such as depletion of the ozone layer; from a focus on protecting certain kinds of wildlife to conserving ecosystems; from controlling trade across borders to controlling activities within national borders that threatened the environment, as by protecting natural world heritage sites, wetlands, and biologically diverse areas. The obligations in the new agreements were generally more detailed and intrusive on national sovereignty than in previous agreements. There is no instance in which provisions in existing agreements have been weakened. Rather they have been strengthened and changes made to make them more effective.

International environmental law also developed significantly in several other areas. Foremost is the 1982 Law of the Sea Convention, which provides unequivocally in Article 192 that states are to protect and preserve the marine environment and in subsequent articles sets forth detailed measures to be taken in order to do so. ${ }^{26}$ Protection of the environment during warfare also emerged as an important subject of international law, as exemplified by the Convention on the Prohibition of Military or any Other Hostile Use of Environmental Modification Techniques, which prohibits the use of those techniques "having widespread, long-lasting or severe effects as the means of destruction, damage or injury to any other State Party."

22 Vienna Convention for the Protection of the Ozone Layer, March 22, 1985, United Nations Treaty Series, Vol. 1513, p. 293 (No. 26164); The Montreal Protocol on Substances that Deplete the Ozone Layer (adjusted and/or amended in London 1990, Copenhagen 1992, Vienna 1995, Montreal 1997, Beijing 1999), United Nations Treaty Series, Vol. 1522, p. 3 (No. 26369).

23 United Nations Framework Convention Climate Change, supra note 18; The Kyoto Protocol to the United Nations Framework Convention on Climate Change, December 10, 1997, United Nations Treaty Series, Vol. 2303, p. 162 (No. 30822).

${ }^{24}$ World Health Organization Framework Convention on Tobacco Control, June 16, 2003 , United Nations Treaty Series, Vol. 2302, p. 166 (No. 41032).

25 Edith Brown Weiss, supra note 19.

26 United Nations Convention on the Law of the Sea, with Annexes and Index, December 10, 1982, United Nations Treaty Series, Vol. 1833, p. 3 (No. 31363).

27 Article 1, Convention on the Prohibition of Military or any Hostile Use of Environmental Modification Techniques (ENMOD Convention), May 18, 1977, United Nations Treaty Series, Vol. 1108, p. 151 (No. 17119). The Convention covers techniques that change "through the deliberate manipulation of natural processes, the dynamics, composition or 
Scientific uncertainty regarding the natural system, our interactions with it, and the effect of our products on it is inherent in international environmental law. Our scientific understanding is always changing. Early international agreements generally did not provide for adjusting to changes in our scientific knowledge of and understanding of environmental issues. Those negotiated after 1970 increasingly made such provision. Sometimes this took the form of provision for regular technical assessments by experts, for simplified procedures for phasing out harmful chemicals more rapidly than initially agreed, for providing for annexes and simplified procedures for adding to annexes, and for regular meetings of the parties to address changes in scientific understandings. A major challenge is to identify, assess and manage risks to the environment and to human health. Some international agreements thus have provided for monitoring, early warning systems of dangers, and prioritization of risks.

Similarly, some of the agreements during this period were directed to conserving ecosystems, rather than only specific pollutants or sources of pollution. For example, the 1978 Great Lakes Water Quality Agreement broadened the focus of the 1972 Agreement from specific kinds of pollution to protection of basin-wide ecosystems in the Great Lakes. ${ }^{28}$ This led to the inclusion of a Protocol in 1987 to address ground water pollution and atmospheric transport of pollution as issues central to protecting the Great Lakes basin ecosystem. ${ }^{29}$

structure of the Earth." Article 35.3, Protocol Additional to the Geneva Conventions of 1949 (Protocol I), June 8, 1977, United Nations Treaty Series, Vol. 1125, p. 3 (No. 17512) also bans the use of techniques that have "widespread, long-lasting and severe damage to the natural environment," but in contrast to the ENMOD Convention, uses the connecting word "and" rather than "or." More recently, the International Committee of the Red Cross compiled relevant international environmental law in the Guidelines for Military Manuals and Instructions on the Protection of the Environment in Times of Armed Conflict, International Review of the Red Cross, No. 311 (April 30, 1996), available at <http://www.icrc.org/eng/ resources/documents/misc/57jn38.htm>, (accessed June 14, 2011). The U.N. General Assembly recommended the Guidelines to all States for due consideration. See, United Nations General Assembly Resolution 49/50, 49th Sess., Agenda Item 136, Article 11, U.N. Doc. A/RES/49/50 (1995). See also, Richard G. Tarasofsky, "International Law and the Protection of the Environment During International Armed Conflict," in Netherlands Yearbook of International Law, Vol. 24 (1993), pp. 17-79.

28 Canada-United States: Great Lakes Water Quality Agreement, 1978, as amended by the 1983 and 1987 Protocols, Ottawa, November 22, 1978, United States Treaties and Otber International Agreements, Vol. 30, p. 1383. This agreement was amended again in 1993. An up-dated version is available at <http://www.epa.gov/glnpo/glwqa/1978/articles.html\# AGREEMENT\%20BETWEEN\%20CANADA>, accessed June 14, 2011.

29 Ibid. 


\section{From 1992-2012: Maturation and Linkage}

This period begins with the United Nations Conference on Environment and Development and then analyzes developments during the almost two decades following the Conference.

1. 1992: The United Nations Rio Conference on Environment and Development

In June 1992, countries met in Rio de Janeiro, Brazil, to commemorate the twentieth anniversary of the 1972 Stockholm Conference on the Human Environment. The location of the conference in Brazil sent an important message that environment and development were the concerns of all countries, regardless of their stage of economic development. The Rio Conference became an important milestone in the development of international environmental law and policy. The World Commission on Environment and Development (also called the Brundtland Commission), created by the United Nations General Assembly, prepared a report for the Rio Conference, Our Common Future, which made the concept of sustainable development the leitmotif of international environmental policy. States confirmed that the guiding paradigm was sustainable development and thus officially ratified the process of reconciling environment and development that had been begun twenty years previously in Founex, Switzerland.

The Brundtland Commission defined sustainable development as "development that meets the needs of the present without compromising the ability of future generations to meet their own needs." ${ }^{30}$ While the concept is nearly universally accepted, there is no officially agreed definition of sustainable development. One can identify generally accepted characteristics, but still the concept is a fluid one and provides considerable latitude in its implementation. ${ }^{31}$

The Rio Conference produced four important documents for international environmental law: the Rio Declaration on Environment and Development, ${ }^{32}$ which laid the basis for the rapid development of new principles and rules of international environmental law; the U.N. Framework Convention on Climate Change; ${ }^{33}$

30 World Commission on Environment and Development, Our Common Future (1987), pp. 8-9.

31 See e.g., Robert Kates, Thomas Parris, and Anthony Leiserowitz, "What is Sustainable Development? Goals, Indicators, Values and Practice," Environment: Science and Policy for Sustainable Development, Vol. 47, No. 3 (2005), pp. 8-21.

32 Rio Declaration on Environment and Development, Report of the United Nations Conference on Environment and Development, U.N. Doc. A/CONF.151/26/Rev.1 (1992).

33 UNFCC, supra note 18. 
the Convention on Biodiversity ${ }^{34}$; and the very detailed Agenda 21, ${ }^{35}$ which set forth a comprehensive list of actions that States were to take. The Conference also adopted a "Non-legally Binding Authoritative Statement of Principles for a Global Consensus on the Management, Conservation and Sustainable Development of all types of Forests," ${ }^{36}$ and led to the subsequent negotiation of a Convention on Desertification. ${ }^{37}$ It resulted in the establishment of a new institution at the United Nations, the Commission on Sustainable Development, to review progress in implementing Agenda 21.

While governments were the formal actors in reaching agreement on these measures, the Rio Conference is especially noteworthy for the roles that non-governmental organizations (NGOs) and the business sector played. These groups held a parallel forum in Rio, and the NGOs published a daily newsletter, which kept all participants apprised of the events of the previous day. NGOs met actively with government delegations. An NGO had represented the small island states in the negotiations for the United Nations Framework Convention on Climate Change.

In the private sector, the Swiss businessman Stephan Schmidheiny founded the World Business Council for Sustainable Development, ${ }^{38}$ which blazed the path for other business groups to become important global players in developing environmental standards, codes, and practices. (The concern of business with sustainable development in turn contributed to the focus ten years later at the Johannesburg World Summit on Sustainable Development on public-private partnerships to address environment and development problems.)

\section{After the Rio Conference}

The years since Rio have witnessed major developments in international environmental law and policy. The field has become more robust and more comprehensive. International intergovernmental organizations, civil society, and industry

${ }^{34}$ Convention on Biological Diversity, June 5, 1992, United Nations Treaty Series, Vol. 1760, p. 79 (No. 30619).

35 United Nations Conference on Environment and Development, Agenda 21, U.N. Doc. A CONF.151/26/Rev.1 (1992).

36 Non-Legally Binding Authoritative Statement of Principles for a Global Consensus on the Management, Conservation and Sustainable Development of All Types of Forests, U.N. Doc. A/CONF.151/26 (Vol. III) (1992).

37 United Nations Convention to Combat Desertification in those Countries Experiencing Drought and/or Desertification, Particularly in Africa, June 17, 1994, United Nations Treaty Series, Vol. 1954 , p. 3 (No. 33480).

38 World Business Council on Sustainable Development, see website, available at $<$ http:// www.wbcsd.org>, accessed July 21, 2011. 
associations, as well as other groups have become more important participants. International environmental law has developed close links to trade, human rights, and national security. New principles and rules have emerged and been refined. The focus has shifted from a near exclusive concern with negotiating new legal instruments to one concerned with implementing and complying with international agreements.

These developments can be grouped as follows: 1) the linkage of international environmental law with other areas of law - namely, international economic law, human rights law, and national security law; 2) the rise of actors other than States in shaping international environmental law, namely the multilateral development banks through their policies and procedures, the private sector through voluntary codes of conduct and green standards, public-private partnerships, and stockholder efforts, and nongovernmental organizations and civil society generally through diverse means; 3) the development and refinement of new international principles and rules of international environmental law and the increase in nonlegally binding instruments; and 4) a new emphasis on implementation of and compliance with international environmental agreements. In addition, new concerns with institutional and environmental governance issues have emerged. ${ }^{39}$

(1) Linkages

(a) Economic Law: Trade and Investment

For more than a decade before the World Trade Organization was formed, the General Agreement on Tariffs and Trade had recognized environmental concerns in its Article XX(b) and (g) exceptions, though the language does not contain the word "environment." tablish a Group on Environmental Measures and International Trade, though it did not meet until 1991. When the WTO was negotiated in 1994, it contained in its preamble reference to the aim of "sustainable development." Since then, major disputes have come before the WTO Dispute Settlement Panels and Appellate Body that raise the potential conflict of national legislation allegedly directed to protecting the environment with the rules of the WTO. ${ }^{42}$ The WTO has a Committee

39 See e.g., Norichika Kanie and Peter Haas, eds., Emerging Forces in Environmental Governance (2004).

40 The General Agreement on Tariffs and Trade, United Nations Treaty Series, October 30, 1947, Vol. 55, p. 187 (No. 814).

11 Marrakesh Agreement establishing the World Trade Organization, with Annexes, Final Act and Protocol, April 15, 1994, United Nations Treaty Series, Vol. 1867, p. 154 (No. 31874).

${ }^{42}$ Appellate Body Report, United States - Standards for Reformulated and Conventional Gasoline, WT/DS2/AB/R (1996) modifying the Panel Report, United States - Standards for Reformulated and Conventional Gasoline, WT/DS2/R; Appellate Body Report, European 
on Trade and Environment, which is studying, among other topics, the relationship between multilateral environmental agreements and the WTO. It has not reached agreement on this or other issues. ${ }^{43}$

The North American Free Trade Agreement (NAFTA) between Canada, Mexico and the United States demonstrates the linkage between trade and environment. The agreement contains an historic provision in Article 104 that if there is an inconsistency between NAFTA and trade provisions in certain environmental agreements, the latter can trump the NAFTA provisions. ${ }^{i 4}$ The three multilateral environmental agreements that the countries have listed are those dealing with trade in endangered species, in hazardous wastes, and in substances that deplete the ozone layer. ${ }^{45}$

A North American Agreement on Environmental Cooperation between Canada, Mexico and the United States was negotiated at nearly the same time as NAFTA as a way to accommodate countries' concerns about environmental protection and to ensure that the trajectory of national protection of the environment would be upward rather than a race to the bottom ${ }^{46}$ Under the Agreement, a resident of any of the three countries can complain to the Secretariat that a country is not enforcing

Community Measures Concerning Meat and Meat Products (Hormones), WT/DS26/AB/R, WT/DS48/AB/R (1998); Appellate Body Report, United States-Import Probibition of Certain Sbrimp and Sbrimp Products, WT/DS58/AB/R (1998); Appellate Body Report, European Communities - Measures Affecting Asbestos and Asbestos-Containing Products, WT/DS135/ $\mathrm{AB} / \mathrm{R}$ (2001) modifying the Panel report, European Communities - Measures Affecting Asbestos and Asbestos-Containing Products, WT/DS135/R (2000); Appellate Body Report, Brazil - Measures Affecting Imports of Retreaded Tyres, WT/DS332/AB/R (2007) modifying the Panel Report, Brazil-Measures Affecting Imports of Retreaded Tyres, WT/DS332/R (2007) and followed by an Arbitral decision, WT/DS332/16 (2008). All WTO dispute records are available at the WTO website <www.wto.org $>$.

43 For information on the Committee on Trade and the Environment see, <http://www.wto. org/english/tratop_e/envir_e/wrk_committee_e.htm>, accessed June 28, 2011. See also the Committee's current report, Report of the Committee on Trade and Environment in Special Session to the Trade Negotiations Committee, TN/TE/20 (April 2011), available at <http:// www.wto.org/english/tratop_e/dda_e/chair_texts11_e/chair_texts11_e.htm>, accessed June $28,2011$.

44 See the North American Free Trade Agreements (NAFTA), December 17, 1992, International Legal Materials, Vol. 32 (1993), p. 289, available at <http://www.sice.oas.org/trade/nafta/ chap-01.asp>, accessed June 28, 2011.

45 Washington Convention on International Trade in Endangered Species of Wild Fauna and Flora (CITES), supra note 16; Basel Convention on the Control of Transboundary Movements of Hazardous Wastes and Their Disposal, United Nations Treaty Series, Vol. 1673, p. 57 (No. 28911); Montreal Protocol on Substances that Deplete the Ozone Layer, supra note 22 .

46 North American Agreement on Environmental Cooperation, September 13, 1993, International Legal Materials, Vol. 32 (1993), p. 1480. 
its environmental laws. If the Commission approves by a two-thirds vote, the Secretariat can prepare a factual record on the complaint, which will be made public by a two-thirds vote of the Commission. As of July 2011, the Commission had received more than 75 complaints and prepared 16 factual records. ${ }^{47}$ Under the Agreement, countries can also decide by a two-thirds vote to institute a dispute settlement process if one country is believed to be engaged in a persistent pattern of failing to enforce its environmental law. This could ultimately lead to trade sanctions. As of July 2011, there were no claims under the latter process.

On the environmental side, the Rio Declaration on Environment and Development addresses in Principle 12 the trade concerns. It provides, inter alia, that "[u]nilateral actions to deal with environmental challenges outside the jurisdiction of the importing country should be avoided." The language uses "should," rather than "shall," which was a nod to the importance of environmental concerns in order to provide a little flexibility in addressing them. Some agreements concluded in 1992 or thereafter include specific provisions addressed to trade concerns. The U.N. Framework Convention on Climate Change, for example, provides in Article 3(5) that "[m]easures taken to combat climate change, including unilateral ones, should not constitute a means of arbitrary or unjustifiable discrimination or a disguised restriction on international trade." 48

Under the Organization for Economic Cooperation and Development (OECD), States approached the linkage between environment and trade by developing formats for a trade review of environmental agreements and for an environmental review of trade agreements. ${ }^{49}$ Government delegations included officials expert in both trade and in environment.

One of the most significant linkages of environment and trade concerns occurs in bilateral free trade agreements. The first United States bilateral free trade agreement to incorporate environmental issues was that between Jordan and the United States. ${ }^{50}$ The pattern has been followed in other United States bilateral free trade agreements, though not necessarily in those between other countries. There have also been efforts to include environment in investment agreements. Under

47 North American Commission on Environmental Cooperation, available at $<$ http://www. cec.org> (accessed July 21, 2011).

48 United Nations Framework Convention Climate Change, supra note 18.

49 Organization for Economic Co-operation and Development, Methodologies for Environmental and Trade Reviews, OECD/GD(94)103 (1994).

so Agreement between the United States of America and the Hashemite Kingdom of Jordan on the Establishment of a Free Trade Area, October 24, 2000, website available at <www. ustr.gov>, accessed July 13, 2011. Article 5 addresses the environment and provides that either party "shall not fail to effectively enforce its environmental law [...] in a manner that affects trade" between the countries (Article 5(3)(a)). 
the auspices of the OECD, States tried to conclude a multilateral investment agreement, but were unsuccessful in doing so. One of the contentious issues in the negotiations was the treatment of environmental issues. ${ }^{31}$

There is now a substantial and growing literature on trade and environment (or environment and trade) issues. ${ }^{52}$ The linkage between the two has become highly significant in the debates about national actions to prevent or mitigate climate change. ${ }^{53}$ We can anticipate that discussion of environment and trade issues will expand in coming years.

\section{(b) Human Rights and Environment}

During the last two decades, environmental law has become increasingly linked with human rights. Some scholars advocate a separate human right to a clean, decent, or healthy environment..$^{54}$ Others argue that existing international human rights law encompasses environment, as in the right to life..$^{55}$ At the national level, a growing number of constitutions recognize such a right, although the exact formulation varies among countries. ${ }^{56}$

s1 Organization for Economic Co-operation and Development, Draft of The Multilateral Agreement on Investment (1998), available at <http://www1.oecd.org/daf/mai/pdf/ng/ ng987r1e.pdf>, accessed June 28, 2011; see also the OECD Secretariat, Relationships between the MAI and Selected Multilateral Environmental Agreements (MEAs) (1998), available at $<\mathrm{http}: / /$ www.oecd.org/dataoecd/57/26/1922682.pdf $>$ accessed June 28, 2011.

52 See, e.g., Edith Brown Weiss, John H. Jackson and Nathalie Bernasconi Osterwalder, Reconciling Environment and Trade (2nd ed., 2008) for a general bibliography of books, monographs and periodicals, and relevant internet sites; Steve Charnovitz, "The WTO's Environmental Progress," Journal of International Economic Law, Vol. 10 (2007), pp. 685708; Robert Housman, The Use of Trade Measures in Selected Environmental Agreements (2005); Andreas Ziegler, Trade and Environmental Law in the European Community (1996).

53 See, e.g., Gary Clyde Hufbauer, Steve Charnovitz and Jisun Kim, Global Warming and the World Trading System (2009); United Nations Environment Programme and World Trade Organization, Trade and Climate Change: A Report by the United Nations Environment Programme and the WTO (2009).

54 Dinah Shelton, "Human Rights, Environmental Rights and the Right to Environment," Stanford Journal of International Law, Vol. 28, (1991), pp. 103-138; Janusz Symonides, "The Human Right to a Clean, Balanced and Protected Environment," International Journal of Legal Information, Vol. 20 (1992), pp. 24-40; Barry Hill, Steve Wolfson and Nicholas Turg, "Human Rights and the Environment: A Synopsis and Some Predictions," Georgetown International Environmental Law Review, Vol. 16, No. 3 (2004), pp. 359-402.

55 Philip Alston, "Conjuring up New Human Rights: A Proposal for Quality Control," American Journal of International Law, Vol. 78 (1984), pp. 607-621; Louis B. Sohn, "The New International Law: Protection of the Rights of Individuals rather than States," American University Law Review, Vol. 32 (1982), pp. 59-63.

56 See, e.g., Constitution of Chile, Article 19, which gives individuals "a right to live in an environment free of contamination" and in Article 20 provides for an action to enforce the 
In international environmental law, the 1972 Stockholm Declaration on the Human Environment provides a basis for linking human rights to the quality of the environment. Principle 1 provides that "[m]an has the fundamental right to freedom, equality, and adequate conditions of life, in an environment of a quality that permits a life of dignity and well-being [...]." Principle 1 of the 1992 Rio Declaration on Environment and Development provides that human beings "are entitled to a healthy and productive life in harmony with nature," but the principle does not refer to a right. At the regional level, the 1981 African Charter of Human and People's Rights, which became effective in 1986, provides that "[a]ll peoples shall have the right to a general satisfactory environment favorable to their development,"57 and the Additional Protocol to the American Convention on Human Rights in 1988 provides that "[e]veryone shall have the right to live in a healthy environment." The European Convention on Human Rights does not explicitly provide for a right to environment, though the European Court of Justice has drawn links between protection of human rights and protection of the environment. ${ }^{59}$

In the United Nations, a draft Declaration of Principles on Human Rights and the Environment was prepared more than 15 years ago, but it was never adopted. ${ }^{6}$

right, Constitution of Chile (1980); Article 24, Constitution of the Republic of South Africa (1996), and Constitution of Ecuador, Article 14, Chapter Two of Title Two, Constitution of Ecuador (2008). For a list of constitutional provisions for environmental rights and duties, see, e.g., Edith Brown Weiss, In Fairness to Future Generations (1998), Appendix B (also published in Japanese, French, Spanish, and Chinese).

57 Article 24, Banjul Charter of Human and Peoples Rights (1981), International Legal Materials, Vol. 21, (1982) p. 58; available at <http://www.achpr.org/english/_info/charter_ en.html> (accessed June 29, 2011). The SERAC case holding by the African Commission on Human and Peoples' Rights provides a powerful precedent for interpreting this Charter provision. See, Social and Economic Rights Action Center $E$ the Center for Economic and Social Rights v. Nigeria, Communication No. 155/96, available at <http://www.escr-net. org/usr_doc/serac.pdf > accessed June 29, 2011.

58 Additional Protocol to the American Convention on Human Rights in the Area of Economic, Social and Cultural Rights, International Legal Materials, Vol. 28 (1988), p. 156. Article 11, "Right to a healthy environment," proclaims "(1.) Everyone shall have the right to live in a healthy environment and to have access to basic public services and (2.) The States parties shall promote the protection, preservation and improvement of the environment."

59 For related analysis, see Richard Desgagne, "Integrating Environmental Values into the European Court of Human Rights," American Journal of International Law, Vol. 89, No. 2 (1995), pp. 263-294; Daniel Garcia San José, Environmental Protection and the European Convention on Human Rights (2005). The Parliamentary Assembly has made three official recommendations (not adopted by the Committee of Ministers) for the inclusion of "Human Right to a Healthy and Clean Environment" in the European Convention. See, PA Recommendations 1130 (1990), 1431 (1999) and 1614 (2003).

60 Draft Declaration of Principles on Human Rights and the Environment, July 6, 1994, U.N. 
Recently, the United Nations Human Rights Council adopted two resolutions relating to climate change and human rights ${ }^{61}$ and, in 2010, a resolution on a right to water and sanitation. ${ }^{62}$ States have yet to declare that the right to environment exists as a human right. During the last two decades, the literature regarding a human right to environment has expanded significantly. ${ }^{63}$ Moreover, certain national tribunals have recognized a right to environment as implicit in other provisions of human rights incorporated in their own national constitutions. ${ }^{64}$

\section{(c) National Security and Environment}

As indicated previously, agreements governing the military or hostile use of techniques for modifying the environment were concluded before 1992 . In the two decades since, there has been growing recognition that national security requires a robust environment. Thus, protection of the environment has been increasing in-

Doc. E/CN.4/Sub.2/1994/9 (1994), Annex 1.

61 The U.N. Human Rights Council adopted its first resolution on "human rights and climate change" (res. 7/23) on March 28, 2008. Pursuant to this resolution, the Office of the High Commissioner for Human Rights prepared a study on the relationship between climate change and human rights (U.N. Doc. A/HRC/10/61 (2009)) for the Council meeting in March 2009. On March 25, 2009, the Council adopted resolution 10/4 "Human rights and climate change." See, <http://www2.ohchr.org/english/issues/climatechange/index.htm> for analysis and link to the resolutions; (accessed June 29, 2008). The Center for International Environmental Law also maintains a website dedicated to human rights and climate change, with discussion of the U.N. Human Rights Council resolutions; see, <http://www.ciel.org/ Hre/UN_Resolution_26Mar08.html>, accessed June 29, 2011.

62 U.N. General Assembly Resolution, U.N. Doc. A/RES/64/292 (July 28, 2010), available at <http://www.un.org/en/ga/64/resolutions.shtml>, accessed June 29, 2011; and Human Rights Council Resolution, U.N. Doc. A/HRC/RES/15/9 (October 6, 2010), available at <http://www.un.org/ga/search/view_doc.asp?symbol=A/HRC/RES/15/9>, accessed June 29, 2011.

63 See, for example, Dinah Shelton, "Human Rights and the Environment: What Specific Environmental Rights Have Been Recognized?," Denver Journal of International Law \& Policy, Vol. 35 (2007), pp. 129-172; Stephen Humphreys, ed., Human Rights and Climate Change (2010); Tyler Gianni and Jed Greer, Earth Rights: Linking the Quests for Human Rights and Environmental Protection (1999).

64 The Indian Supreme Court found, for example, that, "[the] [r]ight to live is a fundamental right under Article 21 of the Constitution and it includes the right of enjoyment of pollution free water and air for full enjoyment of life. If anything endangers or impairs that quality of life in derogation of laws, a citizen has right to have recourse to Article 32 of the constitution for removing the pollution of water or air which may be detrimental to the quality of life." Subbash Kumar v. State of Bibar, (1991) 1 S.C.R. 5, 13. See also, Indian Council for Enviro-Legal Action v. Union of India, (1996) 2 S.C.R. 503, 536-37 and C. M. Abraham, Environmental Jurisprudence in India (1999), p. 136. There are similar decisions in Pakistan, Nepal, and Bangladesh. 
cluded as an aspect of national security. ${ }^{65}$ With projected climate change and anticipated shortages of fresh water resources in such areas as the Middle East, northern and eastern Africa, South Asia, among others, water is increasingly viewed within the lens of national security. ${ }^{66}$

One aspect of the linkage between environment and security relates to the conditions by which environmental agreements must be respected during armed conflict. During the conflict in the Balkans, for example, World Heritage sites were threatened or destroyed. The 1996 Advisory Opinion of the International Court of Justice on Legality of the Threat or Use by a State of Nuclear Weapons observed that the issue was not whether the treaties applied during armed conflict but "rather whether the obligations stemming from these treaties were intended to be obligations of total restraint during military conflict." ${ }^{67}$ This question remains. Another linkage between environment and national security arises during peace time. Some of the policies adopted by governments during peace time to enhance national security may be harmful to the environment. ${ }^{68}$ These include ones relating to nuclear energy, disposal and storage of wastes related to weapons, etc. This points to the importance of integrating environmental concerns into the design and implementation of these laws and policies.

For purposes of examining the evolution of international law, it suffices to recognize that there is a longstanding link between environment and armed conflict, that this link continues to be relevant and to grow, that the link also exists during peace time, and that the environment, and especially water resources, has become part of the prism of national security for some, if not all, States.

\section{(2) The Role of Actors Beyond States}

Some of the most important developments in international environmental law in the last two decades have occurred in multilateral development banks and in the private sector, including both the business sector and nongovernmental organizations. While the environmental measures have not taken the form of agreements negotiated between States, they nonetheless form part of the broader corpus of

65 See, for example, Thomas Homer-Dixon and Jessica Blitt, eds., Ecoviolence: Links among Environment, Population and Security, (1998); and In-Taek Hyun and Miranda Schreurs, eds., The Environmental Dimension of Asian Security: Conflict and Cooperation over Energy, Resources and Pollution (2007).

66 Intergovernmental Panel on Climate Change (IPCC), Fourth Assessment Report: Climate Change 2007 (AR4) (2007), available at <www.ipcc.ch>, (accessed July 13, 2011). See, Jutta Brunnée and Stephen Toope, "Environmental Security and Freshwater Resources: Ecosystem Regime Building," American Journal of International Law, Vol. 91 (1997), pp. 26-59.

67 Legality of the Threat or Use of Nuclear Weapons, supra note 13, pp. 241-242, para. 30.

68 John McNeil and Paul Kennedy, Sometbing New Under the Sun: An Environmental History of the Twentieth Century World (2000). 
international environmental law. These actors have significantly shaped all aspects of international environmental law.

\section{(a) Multilateral Development Banks}

In the 1970s, the World Bank initiated policies and procedures that covered specific environmental impacts of Bank-financed projects, and hired an Environmental Advisor. These efforts substantially increased after 1992, when the World Bank adopted a broad range of policies and procedures intended to protect the environment and to ensure that economic development is sustainable. These new policies and procedures were developed to guide the choice and design of projects and national policies over and above the specific environmental impact of Bankfinanced projects. The so-called "safeguard" policies included policies on environmental assessment, natural habitat, forests, pesticides, dams, indigenous peoples, cultural properties, and resettlement. ${ }^{69}$ Some have been revised at least once during this period. Other regional development banks and the International Finance Corporation have adopted their own versions of some of these policies. ${ }^{70}$ These policies and procedures provide a common template of requirements that apply across countries. Some scholars have identified an emergence more broadly of

6 World Bank safeguard policies include Environmental Assessment, Operational Policy 4.01 (1999), available at <http://go.worldbank.org/K7F3DCUDD0>; Natural Habitat, Operational Policy 4.04 (2001), available at <http://go.worldbank.org/PS1EF2UHY0>; Forests, Operational Policy 4.36 (2002), available at <http://go.worldbank.org/T22VSH6ZE0>; Pest Management, Operational Policy 4.09 (1998), available at <http://go.worldbank.org/ B7525J6000>; Safety of Dams, Operational Policy 4.37 (2001), available at <http://go. worldbank.org/6G6AB69P30>; Indigenous Peoples, Operational Policy 4.10 (2005), available at <http://go.worldbank.org/IBZABS9UU0>; Physical Cultural Resources, Operational Policy 4.11 (2006), available at <http://go.worldbank.org/UBUBZD7NA0>; and Involuntary Resettlement, Operational Policy 4.12 (2001), available at <http://go.worldbank.org/ ZDIJXP7TQ0>, all accessed June 29, 2011.

70 The International Finance Corporation adopted Environmental and Social Safeguard Policies and a Disclosure Policy in 1998. In 2006, it adopted a new Policy on Social and Environmental Sustainability, which strengthens and expands upon the old policy. The IFC applies the 2006 policy to all investment projects. For comprehensive information on the IFC policies and standards see <http://www.ifc.org/ifcext/sustainability.nsf/Content/ EnvSocStandards>, accessed July 21, 2011. The Asian Development Bank's new Safeguard Policy Statement (SPS) was approved in 2009. The 2009 SPS creates a unified policy framework for environment, involuntary resettlement and indigenous peoples. Asian Development Bank, Safeguard Policy Statement (2009) available at $<\mathrm{http}: / / \mathrm{www}$.adb.org/ Documents/Policies/Safeguards/Safeguard-Policy-Statement-June2009.pdf $>$, accessed June 29, 2011. The Inter-American Development Bank, the African Development Bank and the European Bank for Reconstruction and Development have also developed somewhat similar policies. 
"global administrative law."

(b) The Private Sector

Since 1992, the private sector has launched significant efforts to develop its own transnational environmental standards and practices. These may, in effect, pre-empt what governments might otherwise undertake. Private codes of environmental practice include the International Organization for Standardization (ISO) environmental management standards, ${ }^{72}$ the standards for sustainable tropical timber trade and sustainable fisheries, ${ }^{73}$ the International Chamber of Commerce's (ICC) Business Charter for Sustainable Development, ${ }^{74}$ the Responsible Care Program of the Chemical Manufacturers Association, ${ }^{75}$ the Coalition for Environmentally Responsible Economies' (CERES) principles, ${ }^{76}$ the Equator Principles for private international banks, ${ }^{77}$ and numerous private code initiatives, particularly within Europe.

There have also been several important international initiatives under U.N. auspices that are aimed at the private sector, including the 1999 Global Compact, ${ }^{78}$

${ }^{71}$ See, e.g., Benedict Kingsbury, Nico Krisch, and Richard Stewart, "The Emergence of Global Administrative Law," Law and Contemporary Problems, Vol. 68 (2005), pp. 15-61.

72 International Organization for Standardization, ISO 1400O-Environmental Management (1999-2010), available at <http://www.iso.org/iso/standards_development.htm> (search, "environmental standards"), accessed June 29, 2011.

73 For example, the Forest Stewardship Council, Principles and Criteria for Forest Stewardship (first issued in 1993; last amended in 2002) available at <http://www.fscus. org/standards_criteria/>, accessed June 30, 2011; Marine Stewardship Council (MSC) sustainable fisheries standards. The MSC was established in 1997 through the partnership of Unilever and the World Wildlife Federation (WWF). For current MSC standards, methodologies and directives see <http://www.msc.org/documents/scheme-documents>, accessed June 30, 2011.

74 International Chamber of Commerce/World Business Organization (ICC), Business Charter for Sustainable Development: Principles for Environmental Management (1991), available at <http://www.iccwbo.org/policy/environment/id1309/index.html>, accessed June 29, 2011.

75 International Council of Chemical Associations, Responsible Care Initiative (1985), available at <http://www.icca-chem.org/en/Home/Responsible-care/>, accessed June 29, 2011.

76 Coalition for Environmentally Responsible Economies (CERES), The Ceres Principles (1989), available at <http://www.ceres.org/about-us/our-history/ceres-principles>, accessed June 29, 2010.

$\pi$ Equator Principles Association, Equator Principles (2006), available at <http://www. equator-principles.com/ $>$, accessed June 29, 2011. The principles were initiated in 2003 and revised in 2006 to ensure that they were consistent with the new IFC Performance Standards. The Equator Principles apply to project financing with capital costs above $\$ 10$ million.

78 United Nations, United Nations Global Compact (1999), available at <http://www. 
the 1997 Global Responsibilities Index and Sustainability Report Guidelines of $2002,{ }^{79}$ the United Nations Environment Programme Finance Initiative to promote links between sustainability and financial performance,,$^{80}$ and the 2006 Principles for Responsible Investment. ${ }^{81}$ In 2002, the World Summit on Sustainable Development in Johannesburg called for public-private partnerships to promote sustainable development. These partnerships have become central to the mission. They are numerous and becoming more organized and ambitious in their programs, although information about them has been scattered. ${ }^{82}$ As these initiatives demonstrate, in the twenty years since the Rio Conference, the private sector has become an important actor in implementing sustainable development.

\section{(c) Nongovernmental Organizations (NGOs) and Civil Society}

While States continue to be central to the development and implementation of international environmental agreements, nongovernmental organizations have also become very important, both internationally, nationally, and locally, in protecting the environment and ensuring sustainable development. The number of active NGOs has increased dramatically during this period in nearly all countries. At the 2002 Johannesburg Summit, 3,200 NGOs were accredited to participate. ${ }^{83}$ NGOs have participated in meetings of parties for many of the international environmental agreements, assisted countries in developing positions by providing information, analysis, and even draft treaty text, alerted secretariats to violations of the agreements, and brought complaints to bodies set up under certain agreements to monitor and ensure compliance with the provisions of the agreement.

With advances in information technology, which permit informal ad boc groups to form almost instantaneously around certain issues and to disband as

unglobalcompact.org/AboutTheGC/TheTenPrinciples/index.html>, accessed June 29, 2011.

79 The Global Responsibilities Index (GRI), started in 1997, and is now the publisher of the Sustainability Reporting Guidelines. See GRI's 2006 version of the Guidelines, available at <http://www.globalreporting.org/NR/rdonlyres/ED9E9B36-AB54-4DE1-BFF25F735235CA44/0/G3_GuidelinesENU.pdf>, accessed June 29, 2011.

so United Nations Environment Programme, United Nations Environment Program Finance Initiative (1992), available at <http://www.unepfi.org/>, accessed June 29, 2011.

${ }_{81}$ United Nations Environment Programme, Principles for Responsible Investment (2005), available at <http://www.unpri.org/>, accessed June 29, 2011.

82 Marc Levy and Marina Chernyak, "Sustainable Development Partnerships," Environment: Science and Policy for Sustainable Development, Vol. 48 (2006), pp. 3-4.

83 Michele M. Betsill and Elisabeth Corell, eds., NGO Diplomacy: The Influence of Nongovernmental Organizations in International Environmental Negotiations (2008), p. viii. For related analysis of the growth of environmental groups in Japan, see Pradyum Prasad Karan and Unryu Suganuma, eds., Local Environmental Movements: A Comparative Study of the United States and Japan (2008). 
quickly, individuals will likely play an increasingly visible role in drawing attention to environmental problems, in using law to address the problem, and in seeking compliance with international environmental agreements (or potentially in avoiding compliance).

(3) Advances in Principles and Obligations in International Environmental Law

The 1992 Rio Declaration on Environment and Development provided a basis for further development of principles and obligations in international environmental law. Some of these developments are highlighted below.

Principle 7 of the Rio Declaration provided that "[i]n view of the different contributions to global environmental degradation, States have common but differentiated responsibilities." References to "common but differentiated responsibilities," while new then, have become common in international legal parlance. The concept underlies the negotiations on climate change.

Other principles that have been become common in international legal parlance in the last two decades include intergenerational equity, precautionary principle or approach, polluter pays principle, and, according to some scholars, sustainable development. A principle of solidarity recently was proposed. ${ }^{84}$

One of the most significant developments since 1992 is that the International Court of Justice recognized the essence of Principle 21 of the 1972 Stockholm Declaration on the Human Environment as part of international law. ${ }^{85}$ In effect, a State's responsibility includes an obligation related to protecting the environment.

There are also procedural obligations that have developed into obligations in international law in the years since the Rio Declaration, or are in the process of becoming obligations. These include notice, consultation, environmental impact assessment, access to information, public participation, effective access to judicial

s4 Rüdiger Wolfrum and Chie Kojima, eds., Solidarity: A Structural Principle of International Law (2010).

ss Legality of the Threat or the Use of Nuclear Weapons, supra note 13, pp. 241-242, para. 29. The Court stated that "the general obligation of States to ensure that activities within their jurisdiction and control respect the environment of other States or of areas beyond national control is now part of the corpus of international law relating to the environment." The Court reaffirmed this in Gabčikovo-Nagymaros Project, supra note 13, p. 41, para. 53. The Court's language differs slightly from the Stockholm and Rio Declarations language. It uses the term "respect the environment of other States or of areas beyond national control," while Stockholm Principle 21 (and Rio Principle 2) refer to "the responsibility to ensure that activities with their jurisdiction or control do not cause damage to the environment of other States or of areas beyond the limits of national jurisdiction." For related analysis, see Djamchild Momtaz, "Le recours à l'arme nucléaire et la protection de l'environnement," in Laurence Boisson de Chazournes and Philippe Sands, eds., International Law, the International Court of Justice and Nuclear Weapons (1999), pp. 355-374, and Edith Brown Weiss, "Opening the Door to the Environment and to Future Generations," ibid., pp. 338-353. 
and administration redress and remedy, and prior informed consent for some activities. ${ }^{86}$ In 2010 , the International Court of Justice stated that there is now an obligation under general international law for States "to undertake an environmental impact assessment where it is a risk that the proposed industrial activities may have a significant adverse impact in a trans-boundary context, in particular, on a shared resource." ${ }^{\prime 87}$ The Court further noted, however, that general international law did not "specify the scope and content of an environmental impact assessment."

In 1992, States acknowledged in the Rio Declaration on Environment and Development that little progress had been made since 1972 in developing international law regarding liability and compensation for "adverse effects of environmental damage" and urged States to "cooperate in an expeditious and more determined manner" to develop it. However, international environmental law related to liability has still languished, with a few notable exceptions: the Basel Protocol on Liability and Compensation, ${ }^{89}$ the Nagoya-Kuala Lumpur Supplementary Protocol on Liability and Redress to the Cartagena Protocol on Biosafety, ${ }^{9}$ the Protocol on Civil Liability and Compensation for Damage Caused by the Transboundary Effects of Industrial Accidents on Transboundary Waters (to the Convention on the Protection and use of Transboundary Watercourses and International Lakes and the Convention on the Transboundary Effects of Industrial Accidents), ${ }^{91}$ and the International Law Commission's 2006 Principles on the Allocation of Loss in the case of Transboundary Harm Arising out of Hazardous Activities..$^{92}$ As of September 2011, none of the Protocols had gone into effect.

${ }_{86}$ For Japanese scholarship on this development, see, e.g., Toru Iwama, "The Principle of Public Participation in the Management of Natural Resources Embodied in International Environmental Instruments," Seinan-gakuin Daigaku Hogaku Ronsbu [Seinan Law Review], Vol. 33 (2001), pp. 33-66.

${ }_{87}$ Pulp Mills on the River Uruguay (Argentina/Uruguay), I.C.J. Reports 2010, para. 204.

88 Ibid., para. 205.

89 Basel Protocol on Liability and Compensation, December 10, 1999, available at <http:// www.basel.int/pub/protocol.html>, accessed July 23, 2011. It is not yet in effect.

so Nagoya-Kuala Lumpur Supplementary Protocol on Liability and Redress to the Cartagena Protocol on Biosafety, October 15, 2010, available at <http://www.bch.cbd.int/protocol/ NKL>, accessed July 23, 2011.

91 United Nations Economic Commission for Europe, Protocol on Civil Liability and Compensation for Damage Caused by the Transboundary effects of Industrial Accidents on Transboundary Waters, May 21, 2003, available at <http://www.unece.org/env/civilliability/protocol.html>, accessed July 23, 2011.

92 International Law Commission, Draft Principles on the Allocation of Loss in the Case of Transboundary Harm Arising out of Hazardous Activities (2006), submitted to the United Nations General Assembly, which recommended them to governments. Report of the International Law Commission, U.N. Doc. A/61/10 (2006), pp. 106-110. 
Within the last decade, discussions regarding accountability and good governance have raised the question of whether international law may be expanding to encompass these concepts as obligations. To date, there is no consensus on what constitutes good governance, although some core aspects can be identified. ${ }^{93}$ While the term "accountability" appears increasingly in legal literature and is a goal in many international agreements, there is not a consensus on its origin or form. Civil law legal scholars may view accountability as an aspect of responsibility, and hence question separate treatment of it.

Within the last two decades, soft law instruments (or non-legally binding instruments) related wholly or in part to environmental concerns have also increased significantly in number. This reflects a broader trend in certain areas of international law. The Arctic Council, for example, was established by a non-legally binding instrument: the Declaration of the Establishment of the Arctic Council, 1996. ${ }^{94}$ There is still no treaty on the Arctic.

There are many reasons to use "soft law." In some cases, events unfold so quickly that it is preferable to agree upon a non-legally binding instrument than to endure the long process of negotiating a binding one. In other cases, soft law may be a prelude to a later binding agreement. Usually it is easier to reach agreement when the provisions are non-binding and do not have to be consented to by a parliamentary body. ${ }^{95}$

(4) A Focus on Implementation and Compliance with Legal Instruments

Until 1992, states focused primarily on negotiating new legal instruments. By 1993 , as previously mentioned, there were many multilateral agreements, with separate reporting systems, separate secretariats, and with the notable exception of the UN Framework Convention on Climate Change and the Convention on Biodiversity, usually separate financing mechanisms. There was also concern about overlap and inconsistencies between provisions in different agreements, as evidenced by the Convention on Biological Diversity's provision relating to this issue. UNEP tried to address these issues by holding several meetings with the secretariats of various multilateral environmental agreements, by housing some secretariats together in a common building in Geneva, and by other measures. As coun-

93 See Edith Brown Weiss and Ahila Sornarajah, "Good Governance," in Rüdiger Wolfrum, ed., Max Planck Encyclopedia of Public International Law (Online ed., 2010).

94 Declaration on the Establishment of the Arctic Council, September 19, 1996, International Legal Materials, Vol. 35 (1966), p. 1382.

95 For discussion of the role of non-legally binding instruments, see Edith Brown Weiss, ed., International Compliance with Nonbinding Accords (1997); and Dinah Shelton, ed., Commitment and Compliance: The Role of Non-binding Norms in the International Legal System (2000). 
tries approach Rio+20, some of the same issues remain, and there is again talk about "treaty congestion."

Partly as a result of the negotiation of many new agreements during the previous decade before the Rio Conference, a new focus emerged in the scholarly literature and within the United Nations Environment Programme on strengthening implementation of and compliance with existing agreements and on providing ways to do so with future agreements. ${ }^{96}$ The United Nations Environment Programme adopted Guidelines on Compliance with and Enforcement of Multilateral Environmental Agreements and in 2006 published a Manual on the subject. ${ }^{27}$ Increasingly parties to multilateral environmental agreements have established implementation and compliance committees to address problems of noncompliance. They generally let parties address specific cases in flexible ways to meet the underlying reasons for noncompliance and to bring the party into compliance.

Another new approach to strengthening the implementation of multilateral environmental agreements has been the use of market mechanisms. This is especially apparent in the measures available for implementing the Kyoto Protocol to the UN Framework Convention on Climate Change: joint implementation, clean development mechanism, and emissions trading. ${ }^{98}$ The underlying assumption is that by using market mechanisms, countries may be able to implement and comply with the obligations in the agreement with less cost and greater efficiency. Twenty years ago, countries other than the United States were quite skeptical about the use of such market mechanisms. Now, market mechanisms have become part of the implementation armor for international environmental agreements, though they remain controversial, especially on grounds of whether the burden of pollution reduction is borne equitably and of whether they in fact are effective in reducing the targeted pollution.

96 See, e.g., Abram Chayes and Antonia Chayes, The New Sovereignty: Compliance with Treaties in International Regulatory Regimes (1995); Edith Brown Weiss and Harold K. Jacobson, eds., Engaging Countries: Strengthening Compliance with International Environmental Accords (1998), see especially for Japan, James Feinerman and Koichiro Fujikura, "Japan: Consensus-Based Compliance," ibid., pp. 253-290.

${ }_{97}$ The Guidelines have two parts: 1) Guidelines on Enhancing Compliance in Multilateral Environmental Agreements (MEAs) and 2) Guidelines for National Enforcement and International Cooperation in Combating Violations of Laws Implementing Multilateral Environmental Agreements (MEAs). United Nations Environment Programme Guidelines on Compliance with and Enforcement of Multilateral Environmental Agreements, adopted by UNEP decision SS.VII/4; United Nations Environment Programme, Manual on Compliance with Enforcement of Multilateral Environmental Agreements (2006).

${ }_{98}$ Articles 6, 12 and 17 of The Kyoto Protocol to the United Nations Framework Convention on Climate Change, supra note 23. 


\section{Concluding Observations}

In June, 2012, countries will again meet in Rio to celebrate the 20th anniversary of the 1992 U.N. Conference on Environment and Development. Countries will focus on two aspects: 1) development and use of green technology and 2) governance and institutional issues. The field has come far since 1972. Forty years ago, environment was still a relatively obscure subject, and unknown in many countries. In the United States, the first major piece of federal environmental legislation, the National Environmental Policy Act, which initiated the environmental impact assessment, was adopted only in 1969. Most countries had yet to adopt domestic environmental legislation and, as indicated, international agreements were few. This echoed the relatively rudimentary understanding of the environmental system and the impacts that our actions had on the environment. For example, Rachel Carson published her famous book Silent Spring, which alerted the public to the internationally devastating effects of certain chemicals on wildlife, only in $1962 .{ }^{99}$

The subject of human ecology was only beginning to emerge, and did not become fully ensconced as a scientific discipline until the next decade or so. Effects on economic development were only beginning to be identified and appreciated. Thus it is not surprising that there was little international (or national) environmental law before 1972, and that much of it focused on the use and conservation of particular species. The Ramsar Convention on Wetlands in 1971 was a sharp departure from the more traditional approach at that time. To the surprise of some, in just forty years, environment has become an important component of international law, and of domestic laws within countries. Every country now has one or more pieces of environmental legislation or regulation. And as indicated previously, there are now hundreds of bilateral and multilateral environmental agreements or significant non-legally binding instruments concerned with environment. This reflects advances in scientific understanding of the environment, both globally and locally, a recognition of the economic costs of environmental damage and the competitive advantages of environmentally sound production, and an appreciation of the social, health, and economic costs to communities and individuals from degraded environments. The environment has as its constituency the public worldwide. It is an issue to which people can relate at the most local level, and in this sense it is an issue that has both top-down and bottom-up elements.

Some have noted the limits of environmental law. Certainly, one can argue that our accomplishments in ensuring a sustainable human environment lag far behind the enormous task confronting us. While international environmental law is much better, the environment is, at least in some aspects, worse. This leads some to question the value of international environmental agreements.

9 Rachel Carson, Silent Spring (1962). 
Others would note that with environmental law, some aspects, such as air pollution and the robustness of the ozone layer, have considerably improved, and that the environment is better than it would be if we did not have environmental law. There is a strong push for implementing and complying with the laws that we already have, both internationally and domestically. The need to strengthen implementation and compliance is an important item on the international legal agenda.

None of this should obscure the observation that from an historical perspective, international environmental law has evolved rapidly, and continues to do so. The same applies generally to national environmental laws. I would argue further that international environmental law continues to have significant impact in helping shape countries' actions in addressing environmental problems and promoting sustainable development.

As we look to the future, we can anticipate that climate change is likely to dominate the environmental legal agenda, whether explicitly or implicitly. International environmental law will become of necessity more concerned with long-term risks and their assessment and management, and with issues of both inter-generational and intra-generational equity. All of this will take place in a kaleidoscopic world, ${ }^{100}$ in which individuals and ad boc groupings as well as States, international organizations, nongovernmental organization, private sector actors, and networks will co-exist. Change will be rapid and constant, requiring new measures to accommodate it in order to ensure sustainable and equitable development for both present and future generations.

100 Edith Brown Weiss, "International Law in a Kaleidoscopic World," Asian Journal of International Law, Vol. 1, No. 1 (2011), pp. 21-32. 